\title{
Managers' Perception on Public Organizations' Performance and New Public Management during Economic Crises
}

\author{
Submitted 21/12/18, $1^{\text {st }}$ revision $13 / 1 / 19,2^{\text {nd }}$ revision 20/2/19 accepted 26/3/19
}

\author{
Christodoulos K. Akrivos ${ }^{1}$
}

\begin{abstract}
:
Purpose: The main aim of this article is to evaluate the views of civil servants employed in a managerial position in the Greek Parliament, on whether the principles of the new public management would be more effective for the recent economic and financial crisis in Greece.

Design/methodology/approach: The research methodology includes the following: a literature review on the public sector specificities and the principles of the new public management; a primary research conducted as a case study with a structured questionnaire addressed to civil servants working at the Greek Parliament (sample of 20 managers).

Findings: The main conclusion of the survey is that public managers believe that the principles of the new public management should be applied, and what is interesting is the fact that these views remain the same irrespective of the state of the economic crisis.

Practical implications: The results can contribute to improve the effectiveness of public management, employee's satisfaction and motivation so as to improve their work performance. Additionally, the study offers the possibility for a new legal framework in the Greek public sector concerning employee's performance evaluation and rewarding.

Originality/value: The study is unique in its origin as although it examines a well-known tool of public administration which is the new public management theory it is tested under the conditions of an economic crisis in the Greek Parliament from the point of view of a useful tool to get out of the crisis.
\end{abstract}

Keywords: Public Administration, New Public Management, Economic Crisis, Performance Management, Employees Perception.

JEL codes: H12, M12.

Paper type: Case Study Research Paper.

\footnotetext{
${ }^{1}$ Neapolis University of Pafos, Faculty of Economics and Management, Cyprus, Teaching in Master of Public Administration, c.akrivos@nup.ac.cy
} 


\section{Introduction}

The uncertainty at all levels which characterizes our age is perhaps the only certainty that should serve as a key incentive to adapt and change to ever-changing situations (UN, 2018). In particular, in the workplace, the management of all types and size of organizations, both private and public, are facing the need to redeploy their operations in order to be effective (Jurisch et al., 2012). The acute economic crisis that has taken place in Greece has highlighted both the structural and functional weaknesses of the Greek public administration. At this crucial period, the contribution of public administration to the support of Greek society is particularly important (Mavridis, 2018). It is now necessary to implement reforms that will make it more effective and efficient, by saving resources while at the same time upgrading the services provided. In this respect, the necessity of adopting measures that will help to improve the functionality and the flexibility of the public administration, exempting it from the phenomena of typology, legalism and multiplicity, emerges more imperative than ever (Sultanova and Chechina, 2016).

In some cases, the recent reforms under the above objectives, through the transfer of responsibilities and the reorganization of services, have revealed new problems, conflicts and overlapping of responsibilities, with direct negative effects on the quality of the services provided (Prabha et al., 2010). In other cases, legislative initiatives have made administration more effective by addressing areas suffering from chronic malfunctions (Curristine et al., 2007).

Finally, society's need for quality services is reflected in the increasing search by citizens for wider information on administrative issues that concern them and timely handling of their affairs. In this context, transparency is emerging as an essential mechanism for controlling the effectiveness of administrative action and its protection is absolutely necessary.

The aim of this paper is to find the extent to which civil servants in Greece believe that the principles of the New Public Management - NPM in the Greek public sector (Philippidou et al., 2004) should be applied, especially today where the country faces the economic crisis and the memorandums. The main research questions of this study are:

1. Do the civil servants accept the implementation of the NPM today?

2. What elements of NPM are most desirable and which less?

3. Would there be any change in the views of employees if there was no economic crisis?

The Greek Parliament was selected among other public organizations as the closest administrative body to the center of the national strategic decision making and policies. 


\section{Literature Review}

\subsection{Aspects of Public Administration in Greece}

The Greek public administration has had a tremendous impact from the first to the last memorandums which have been signed by the Greek government and the Troika (Hermann, 2014). Troika which consists of the European Commission - EC, the European Central Bank - ECB and the International Monetary Fund - IMF, offers financial assistance to Greece and at the same time supervises the public sector and influences political decisions (Mavrides, 2017; Chronis and Zombanakis, 2016; Thalassinos et al., 2015).

The main issues of the Greek public sector are mentioned in Paragraph C.5.1. of Article 3 of Law 4336/14.9.2015 (3rd memorandum) as follows: "The authorities intend to modernize and strengthen the Greek administration and to implement, in close cooperation with the European Commission, a capacity building program and depoliticisation of the Greek administration". The term "depoliticization" appears in a legislative text for the first time since 1974 to date and it means the separation of the government from the public administration. Also, out of the ten significant Expert Reports of the period 1950-1998, only one in a similar form appears, although most of these Reports suggested measures to promote it. This is the "Report on the Reform and Modernization of Public Administration" by the Ministry of the Presidency of the Government in 1990. The Report identifies, as key factors in the problems of the Public Administration, among other things, "the vicious circle of politicization" and "the perpetuation of perceptions of the political parties control over administration", the "adherence to a formal legalism" and the "degradation and marginalization of the Parliament". It notes that "misplaced and fragmentary reforms have been implemented to suggest a hollow and incomplete global view", proposing " a comprehensive proposal for reform and modernization of the country's administrative system".

The above commitment of the Greek Authorities to the "depoliticisation of the Greek administration" is absolutely correct, but also the most difficult to implement. It is necessary to emphasize that the most correct term is not "depoliticization" but "de-partisation", because Public Administration is a tool for designing and implementing public policies, and is therefore a policy instrument. But if law chooses this term, this will be used. The term departisation on the other hand means that the political parties must not influence the management of the public organizations which is also a necessity for the independence of public management. Addressing these problems cannot be done as if they were endogenous problems of public administration, but as systemic issues (Featherstone, 2005) concerning the relations between Political System - Public Administration - Citizens - Business.

An example of good practices are the follow three decisions: 
1. Changing the relationship of political system - public administration, which can be achieved through a number of decisions such as the managementmanagement policy distinction, which requires the creation of a "Top Managers" pool, from which general and special secretaries of the ministries will come from, heads of public bodies and general directors of ministries, regions, municipalities and their legal entities. The law 4369/2016 is a good practice to this direction although it needs additional measures and commitment from the government.

2. Changing the political system - public administration - business-to-business relations that can be achieved for example by simplifying, objectivity and computerizing the processes of production and provision of services to citizens and businesses so as not to need a "man in Koroni" which means an important person who takes care of your "interests".

3. Establishment of an observatory for the implementation of the above, involving the relevant scientific staff of parliamentary parties, local authorities, social partners and the most important civil society actors. The observatory will ensure transparency and continuous external evaluation of the implementation of these measures.

The above measures correspond to the following "internal and systemic tools" for the reform of the Public Administration:

- Improvement of Public Management through development of human resources.

- Organization and operational modernization services offered to private sector.

Of course there is an alternative to the "depoliticization of the Greek administration" and it is not the classical reforming technique of communication flares but the introduction of new laws which establish objective criteria and a selection procedure for senior managers of the public sector without any political interference which are respected and improved by all governments on long term basis (Spanou, 2015).

\subsection{New Public Management (NPM) and the Greek Public Sector}

The NPM as an issue was emerged in the late 1970s and early 1980s. The scholars who entered the field were located in the United Kingdom under Prime Minister Margaret Thatcher and in the municipal governments in the U.S. (Sunnyvaley, California) that had suffered seriously from economic recession and tax revolts. Afterwards, the governments of New Zealand and Australia adopted the philosophy. Their successes put NPM administrative reforms on the agendas of most OECD countries and other nations as well. This means that economic crisis and NPM are 
interrelated as NPM is considered a useful tool to reorganize the public sector in order to become at least more efficient. According to Grimshaw et al. (2012), although the impact of the crisis was different from country to country, there has been a convergence of measures towards decreasing public spending as opposed to previous economic recessions where public spending was seen as a tool to boost overall demand. In particular, in the case of countries, which have signed memorandums, the minimizing approach seems to have prevailed. As it can be seen from the strict conditions under which financial assistance was granted to countries such as Greece and Portugal, "... public administration was considered by the EU only as a source of public spending that had to be squeezed rather than as a public service provider which had the need to be modernized" (Di Mascio and Natalini, 2015, p. 145). This is the reason why the public sector is at the heart of "conditionality" (the imposition of terms) as a condition for granting financial support to the country (Featherstone, 2015).

In fact, in addition to a number of more general institutional factors, it is mainly the degree of financial vulnerability of each country that contributes to the understanding of the responses given by governments and the consequent impact on working conditions and industrial relations in the public sector (Bach and Bordogna, 2013). Thus, according to a report by the European Commission (2012), although the crisis affected and had an impact on all Member States, there were variations in the size and intensity of the measures, as well as in how the measures were decided. In particular, it is distinguished:

The first group of countries (Greece, Ireland, Portugal) which have implemented the most extensive austerity and restructuring programs in the public sector. The second group of countries, which, although not left unaffected, proceeded to programs mainly by decision of their own national governments. This second group of countries (Spain, Italy, Cyprus) has adopted milder financial measures (freezing instead of wage cuts, hiring restrictions instead of staff reductions).

The main manifestations of this attempt to shrink the public sector are privatization, shrinking employment, as well as changes in labor relations and employment regimes for the public employees. To this direction a number of relevant studies (Kouzis et al., 2012; European Commission, 2013) refer to measures and policies such as:

$\checkmark$ Measures to reduce employment (by freezing recruitment, privatization policies or job cuts, job reserve programs, etc). The target was the special employment status of civil servants often associated with high levels of occupational safety (Bach and Bordogna, 2013).

$\checkmark$ Policies to increase employment flexibility and to reorganize working time.

$\checkmark$ Measures to contain and reduce direct and indirect wages, which, although presented as "one-off" measures to tackle the crisis, tend to be expanded and 
strengthened over time, indicating an ongoing attempt to reduce wages in the public sector (Bach and Bordogna, 2013).

$\checkmark$ Changes in pension arrangements.

$\checkmark$ Measures for revising work organization standards.

Therefore, the image of public employment as protected by international pressure and with national actors to play the leading role was questioned. After all, as in other areas, the so-called "reform" of the public sector, especially in the case of the southern countries, has become a "top-down" process, with government leaders and supranational institutions to take the decisions (Sotiropoulos, 2015). One could say that the public sector has been and is the main area where the EU's "new type of intervention", which is called for by the so-called "New Economic Governance of the EU", emerged. What distinguishes "New Economic Governance" is a rising autocratic, top-down approach with the EU to intervene and directly defining national policies, even in areas where the EU has no formal authority.

This approach was also reflected in the procedures whereby measures were adopted and policies were promoted, particularly in the case of the countries of the European South. In these latter two trends dominated: centralization and unilateralism. The governments of these countries (more indicative of the Greek case), often invoking that "the state is in a state of emergency" argument, voted for measures that ignored or circumvented the agreements with the social partners or without the necessary consultations and discussions. This, coupled with the weakening of the role of the social partners in the design of more general social legislation, constitutes a change in the procedural framework of social legislation which for some fellows is against democracy (Clauwaert and Schömann, 2012, Schömann, 2015).

\section{Research Methodology}

The main aim of this research is to determine the extent to which civil servants have accepted the principles of the NPM following the imposition of memorandums, fiscal reforms and the economic crisis in Greece. The sample of the research was the population of public employees who hold a managerial position in the Greek parliament. Specifically, twenty people participated, 60\% women and 40\% men. They all had a background in the private sector, and their level of study ranges from a B.A. to a Ph.D degree.

Descriptive statistics were used to analyze the data and the data were processed using SPSS V.20. The exploratory method was followed using a structured questionnaire and data collection with primary research. The questionnaire is divided into two parts:

A. The demographic characteristics of the sample. 
B. The degree of acceptance of the NPM for the calculation of which 38 questions were used on a Likert scale to determine the degree of agreement from one to five, starting from strongly disagreeing to strongly agreeing.

The questions reflect the princilples of NPM as they were developed from different point of views and researchers up to day (Lacovino et al., 2017; Asif and Mamoon, 2018; Tabrizi et al., 2018). The principles or the main axes of NPM which have been included are:

1. Business environment and strategic objectives;

2. Organizational structures and processes;

3. Performance management and measurement systems;

4. Management and managers;

5. Employees and corporate culture;

6. Adoption of private sector management logic;

7. Public interest and authority must be above personal interest.

This type of research was chosen because its aim is to explore the current situation and attitude of the public servants who have experienced the crisis and the reforms in the Greek public sector.

\section{Findings and Discussion}

After data elaboration the reliability test shows that the indicator is higher than 50\% as it is reflected in Table 1 below.

Table 1. Reliability Test

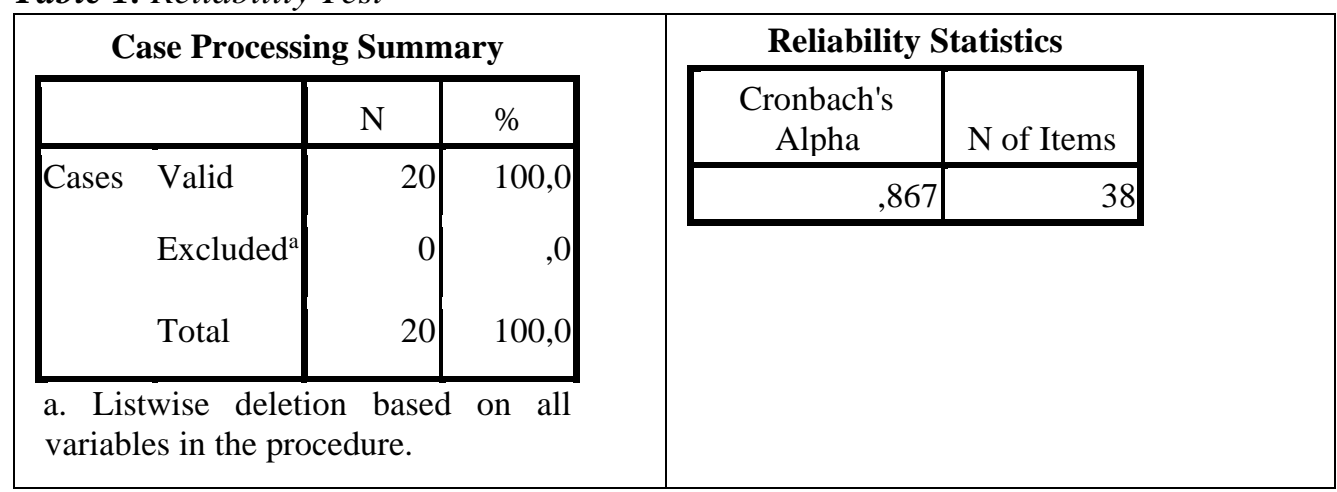

The demographic profile of the research is presented in Table 2 . 
Table 2. Demographics

\begin{tabular}{|c|c|c|c|c|c|}
\hline \multicolumn{6}{|c|}{ Sex } \\
\hline & & Frequency & Percent & Valid Percent & $\begin{array}{c}\text { Cumulative } \\
\text { Percent }\end{array}$ \\
\hline \multirow[t]{3}{*}{ Valid } & Man & 8 & 40,0 & 40,0 & 40,0 \\
\hline & Woman & 12 & 60,0 & 60,0 & 100,0 \\
\hline & Total & 20 & 100,0 & 100,0 & \\
\hline \multicolumn{6}{|c|}{ Age } \\
\hline & & Frequency & Percent & Valid Percent & $\begin{array}{c}\text { Cumulative } \\
\text { Percent }\end{array}$ \\
\hline \multirow[t]{5}{*}{ Valid } & Till 35 & 2 & 10,0 & 10,0 & 10,0 \\
\hline & $36-45$ & 9 & 45,0 & 45,0 & 55,0 \\
\hline & $46-55$ & 8 & 40,0 & 40,0 & 95,0 \\
\hline & Over 55 & 1 & 5,0 & 5,0 & 100,0 \\
\hline & Total & 20 & 100,0 & 100,0 & \\
\hline \multicolumn{6}{|c|}{ Family Status } \\
\hline & & Frequency & Percent & Valid Percent & $\begin{array}{c}\text { Cumulative } \\
\text { Percent }\end{array}$ \\
\hline \multirow[t]{3}{*}{ Valid } & Married & 16 & 80,0 & 80,0 & 80,0 \\
\hline & Single & 4 & 20,0 & 20,0 & 100,0 \\
\hline & Total & 20 & 100,0 & 100,0 & \\
\hline
\end{tabular}

The research data point out that the majority of employees are women which reflects a trend in the Greek public sector as the percentage of women in managerial position is increasing and this is more evident in specific Ministries such as the Ministry of Culture and other public bodies like Courts, where women are the majority at all levels of hierarchy.

A number of statistical significant relations were detected but those which are more relevant to this research are presented in Table 3 below. The significant relationship reflects that employees with longer professional experience - older employees accept performance evaluation as a tool to define wages more than those with less professional experience - the youngsters.

Table 4 is in relation with Table 3 as those who accept to be evaluated consider as necessity that the public management must operate independently from the 
government of the country. This implies that public employees do not trust politicians (among other) as subjective evaluators of their performance.

Table 3. Age and Performance Evaluation

\begin{tabular}{|c|c|c|c|}
\hline \multicolumn{4}{|c|}{ Correlations } \\
\hline & & Age & $\begin{array}{l}\text { Employees Performance Indicators } \\
\text { Must Applied Connected to Wages }\end{array}$ \\
\hline \multirow[t]{3}{*}{ Age } & $\begin{array}{l}\text { Pearson } \\
\text { Correlation }\end{array}$ & 1 &,$- 698^{* * *}$ \\
\hline & $\begin{array}{l}\text { Sig. }(2- \\
\text { tailed) }\end{array}$ & & 001 \\
\hline & $\mathrm{N}$ & 20 & 20 \\
\hline \multirow{3}{*}{$\begin{array}{l}\text { Employees Performance } \\
\text { Indicators Must be Used and } \\
\text { Wages must Reflect Performance }\end{array}$} & $\begin{array}{l}\text { Pearson } \\
\text { Correlation }\end{array}$ &,$- 698^{* * *}$ & 1 \\
\hline & $\begin{array}{l}\text { Sig. }(2- \\
\text { tailed) }\end{array}$ &, 001 & \\
\hline & $\mathrm{N}$ & 20 & 20 \\
\hline
\end{tabular}

Note: **. Correlation is significant at the 0.01 level (2-tailed).

Table 4. Performance Evaluation and Independence of Public Management

\section{Correlations}

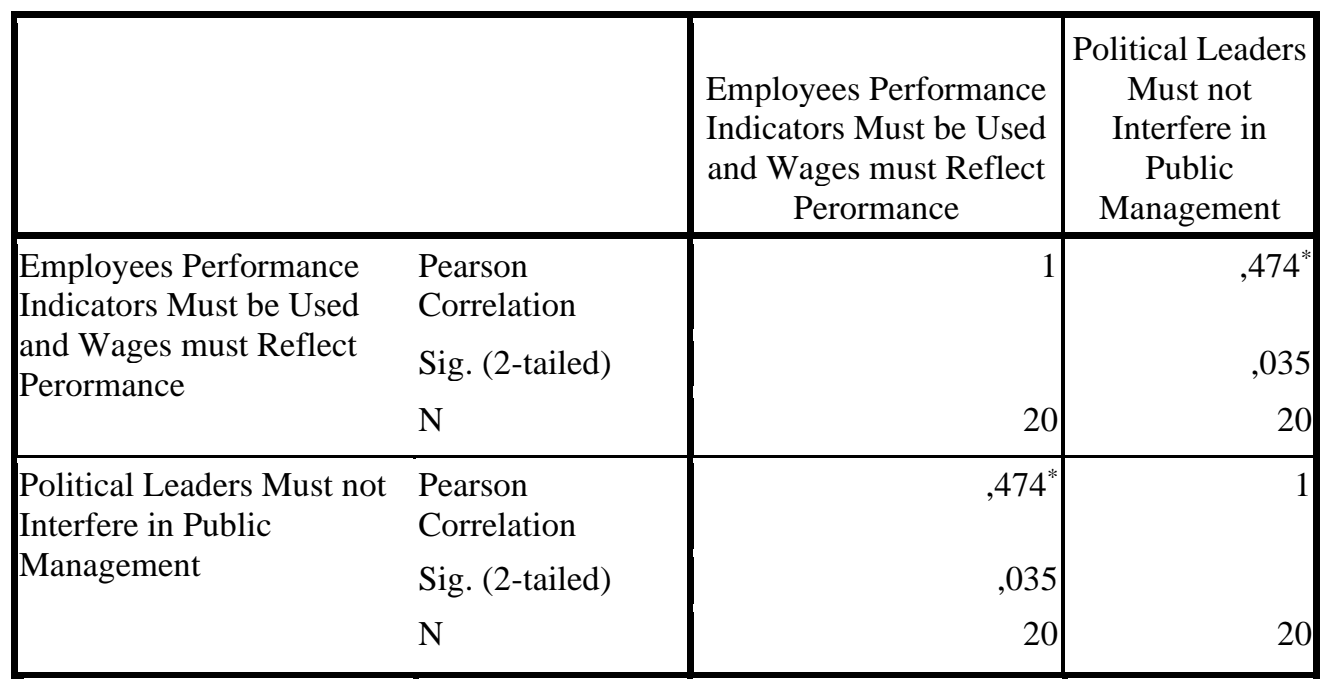

Note: *. Correlation is significant at the 0.05 level (2-tailed). 
The results show that the adoption of private economic criteria in the management of public bodies and the change of the term public administration to public management is generally accepted by the managers. However:

$>$ They do not accept the concept of competition and the provision of competitive services to the citizens.

$>$ They do not accept the fact that public administration decisions should be made mainly by financial criteria, obviously with the view that the public sector also carries out social policy and must provide services to the citizens of the country even if they are not profitable from the economic point of view.

$>$ They are very much in favor of cuts and the elimination of unnecessary spending as a decision to consolidate the public sector and at the same time operate within the budget and not exceed it as is usually the case (Spanou, 2015). At the same time, they believe that it is a necessity for the public organizations to operate more strategically and less by chance or reactively.

$>$ They are significantly interested in increasing productivity in order to be declassified as non-productive and bureaucratic organizations. At the same time, they accept performance appraisal as a measure that will help to increase the productivity of civil servants and make use of metrics such as those mentioned in Law 3230/2004.

$>$ They believe that remuneration should be based on the performance of the civil servant and that there should be reductions in the case of low productivity. In the same vein, the degree of accountability and transparency of civil servants for the work they perform in their duties should be increased. There should also be exemplary punishment for civil servants who exercise power deriving from their position not for the benefit of the society but for their own benefit.

$>$ They are in favor of decentralizing services and moving them closer to the citizen and geographically and accepting citizens' participation in public sector decision-making.

$>$ They do not consider that they should subcontract part of the core productive activity of public bodies and are against privatization apparently for the sake of their job security.

$>$ They believe that new technologies are needed to make organizations more effective. 
$>$ They require systematic scrutiny of public policies (Featherstone, 2005) to reduce political or party interference in the work of civil servants (depoliticization).

$>$ They believe that there is no meritocracy in the public sector and that is why they want to restructure the hierarchy based on the ability and suitability of the person to perform these tasks.

$>$ They do not accept the management of capable executives from the private sector and the market in general but only from the public sector as an effort to protect their interests, but this attitude has as negative the reproduction of more of the same.

Finally, if there was no crisis in Greece today, respondents' responses would remain the same, with the overwhelming majority of $90 \%$ saying they would remain the same, indicating a strong desire to publicly sanction using most of the NPM principles as presented in Table 5.

Table 5. In Case There was not Economic Crisis Would you Alter your Attitude to $N P M$

\begin{tabular}{|ll|r|r|r|r|}
\hline & & & & \multicolumn{2}{c|}{$\begin{array}{c}\text { Cumulative } \\
\text { Percent }\end{array}$} \\
\hline Valid & Dissagree & 1 & 5,0 & 5,0 & 5,0 \\
& Neither Nor & 17 & 85,0 & 85,0 & 90,0 \\
& Agree & 2 & 10,0 & 10,0 & 100,0 \\
Total & 20 & 100,0 & 100,0 & \\
\hline
\end{tabular}

Moreover, apart from the acceptance of a number of NPM principles there is also a part which is rejected for example the privatization (Oravee \& Umealor, 2015) of some public services which are offered in an inefficient way, the principles of profit is not consider important in decision making although in some cases the respondents want to find ways to spend less and more effective.

\section{Conclusion}

Based on the above results and conclusions the following suggestions for public administration would be helpful to improve public organizations' performance:

$>$ Introduction of a system of performance evaluation of the civil servants which must be related to wages and benefits, promotions and discipline.

$>$ Exemplary punishment of public servants who exploit their position for their own benefit. 
$>$ Use of productivity indicators and staff motivation methods to achieve the goals.

$>$ Eliminate unnecessary spending and respect the budget so that there are no debts but surpluses.

$>$ Decentralization of internal processes and geographically so as to improve quality of services offered to citizen.

$>$ The majority of the findings in this research incorporate the principles of Public Governance as it is an essential component of NPM in modern organizations (Klijn, 2012).

\section{References:}

Asif, R., Mamoon, D. 2018. Does new public management practices lead to effective public welfare responses in Pakistan? Turkish Economic Review, 5(2), 150-173.

Bach, S. and Bordogna, L. 2013. Reframing public service employment relations: The impact of economic crisis and the new EU economic governance. European Journal of Industrial Relations, 19, 270-294.

Clauwaert, S. and Schömann, I. 2012. Crisis and National Labour Law Reforms: A mapping exercise. ETUI working papers.

Chronis, P., Zombanakis, G. 2016. An Evaluation of Policies for Fiscal and External Sustainability during the Recent Greek Economic Crisis. European Research Studies Journal, 19(1), 34-44.

Curristine, T., Lonti, Z. and Joumard, I. 2007. Improving Public Sector Efficiency: Challenges and Opportunities. Journal on Budgeting, 7(1), 1-41.

Di Mascio, F. and Natalini, A. 2015. Fiscal retrenchment in southern Europe: Changing patterns of public manage $\neg$ ment in Greece, Italy, Portugal and Spain. Public Management Review, 17(1), 129-148.

Diefenbach, T. 2009. New Public Management in public sector organizations: the dark side of managerialistic 'enlightenment'. Public Administration, 87(4), 892-909.

European Commission 2012. Industrial Relations in Europe 2012. Luxembourg: Publications Office of the European Union.

European Commission 2013. Industrial Relations in Europe 2013. Luxembourg: Publications Office of the European Union.

Featherstone, K. 2005. Introduction: Modernization and the Structural Constraints of Greek Politics, West European Politics (Special issue: The Challenge of Modernization Politics and Policy in Greece), 28(2), 223-241.

Featherstone, K. 2015. External Conditionality and the Debt Crisis: The 'Troika' and Public Administration Reform in Greece. Journal of European Public Policy, 22(3), 295314.

Grimshaw, D., Rubery, J. and Marino, S. 2012. Public sector pay and procurement in Europe during the crisis. EWERC working paper, Manchester Business School.

Hermann, C. 2014. Structural Adjustment and Neoliberal Convergence in Labour Markets and Welfare: The Impact of the Crisis and Austerity Measures on European Economic and Social Models. Competition \& Change, 18(2), 111-130.

Jurisch, M., Ikas, C., Palka, W., Wolf, P., Krcmar, H. 2012. A Review of Success Factors and Challenges of Public Sector BPR Implementations. Proceedings of the Annual Hawaii International Conference on System Sciences. 
Klijn, E.H. 2012. New Public Management and Governance: A Comparison of Two Paradigms to Deal with Modern Complex Problems. In Faur, D. (ed.) The Handbook of Governance, 201-214. Oxford, UK.

Kouzis, G., Georgiadou, P., Kapsalis, A., Kousta, E., Lampousaki, S. 2012. Labour Relations in Europe and in Greece. Annual Review, Scientific Report 8. Observatory of Economical and Social Developments, GSEE Labour Institute.

Lacovino, M., Barsanti, S. and Cinquini, L. 2017. Public Organizations Between Old Public Administration, New Public Management and Public Governance: The Case of the Tuscany Region. Public Organization Review, 17, 61-82.

Mavridis, S. 2018. Greece's Economic and Social Transformation 2008-2017. Social Sciences, 7(6), 1-15.

Oravee, L. and Umealor, C. 2015. New Public Management Principles and Privatization of the Nigerian Public Enterprises: A Study of Benue Hotels. Review of Public Administration and Management, 4(8).

Philippidou, S., Soderquist, E., Prastacos, G. 2004. Public Organizations: Leadership vs. Management, and the Path to Implementation. Public Organization Review: A Global Journal, 4, 317-337.

Prabha, R., Soolakshna, L., Perunjodi, N. 2010. Service quality in the public service. International Journal of Management and Marketing Research, 3(1), 37-49.

Schömann, I. 2015. Réformes Nationales du Droit du Travail en Temps de Crise: Bilan Alarmant pour les Droits Fondamentaux et la Démocratie en Europe. Revue Interventions Economiques, 52 | 2015, mis en ligne le 01 mars 2015, consulté le 30 juillet 2019. URL :

http://journals.openedition.org/interventionseconomiques/2437 ; DOI : 10.4000/interventionseconomiques.2437.

Sotiropoulos, D. 2015. Southern European Governments and Public Bureaucracies in the Context of Economic crisis. European Journal of Social Security, 17(2), 226-245.

Spanou, C. 2015. Administrative Reforms and Policy Conditionality in Greece. Administration and Public Employment Review, (APER), 1, 31-54.

Sultanova, A.V., Chechina, O.S. 2016. Human capital as a key factor of economic growth in crisis. European Research Studies Journal, 19(S2), 71-78.

Tabrizi, S., Goshayie, H., Doshmangir, L, Yousefi, M. 2018. The Barriers to Implementation of New Public Management Strategies in Iran's Primary Health Care: A Qualitative Study. Uni Med Health Science, 17(01), 8-17.

Thalassinos, I.E., Stamatopoulos, D.T. and Thalassinos, E.P. 2015. The European Sovereign Debt Crisis and the Role of Credit Swaps. Chapter book in The WSPC Handbook of Futures Markets (eds) W. T. Ziemba and A.G. Malliaris, in memory of Late Milton Miller (Nobel 1990) World Scientific Handbook in Financial Economic Series Vol. 5, Chapter 20, pp. 605-639, ISBN: 978-981-4566-91-9, (doi: 10.1142/9789814566926_0020).

United Nations. 2018. World Economic Situation and Prospects. NY. 